\title{
Information and Communication Technology Usage and Bank Branch Performance
}

\author{
H. M. C. M. Maldeni and Sanath Jayasena
}

\begin{abstract}
This research study aims to provide an analysis on the relationship between Information and Communication Technology (ICT) usage and overall performance of bank branches done from a perspective of a leading commercial bank in Sri Lanka. Most of the banks in Sri Lanka are geared for comprehensive banking solutions with extensive branch networks. Empirical data collection was done in the year 2008 and analyzed with the theoretical data. A sample of 18 branches was selected using the non-probability sampling technique. Perceptions of branch managers, staff members and customers were collected using a survey method. All 18 branches selected are of an equivalent grade according to the grading set by the bank. Three types of questionnaires were designed for branch managers, branch staff and customers. Both structured and semi structured questions were included in the questionnaires with 5 point and 4 point likert scale.

Data analysis was done using bivariate correlation and linear regression. Pearson's correlation coefficient was used to measure the linear relationship between variables. The analysis revealed that ICT usage has a positive linear relationship with financial performance and quality performance of bank branches. Bank branch performance was found to have a correlation with factors such as staff attitude towards ICT usage, ICT literacy level of branch staff and scope and complexity of the ICT applications.
\end{abstract}

Index Terms-Bank branch performance, Benchmarking, Decision making units, Financial Performance, ICT literacy level, Information and communication technology usage, Quality Performance.

\section{INTRODUCTION}

\section{A. Background and Motivation}

Tnformation and Communication Technology (ICT) is fast becoming a dynamic channel that drives the Sri Lankan economy. ICT is becoming increasingly important for the growth of our economy as a whole.

Manuscript received June 30, 2009. Accepted October 19th, 2009.

HMCM Maldeni, 277/2, Second Lane, Rattanapitiya, Boralesgamuwa, Sri Lanka (e-mail: mmaldeni@yahoo.co.uk).

S. Jayasena, is with Department of Computer Science and Engineering, University of Moratuwa, Sri Lanka. (sanath@, uom.lk).
The availability and usage of adequate ICT skills are important factors, which influence the competitiveness among commercial banks in this era of e-Economy.

There are multiple factors which govern the performance of an organization. Of those, ICT has a significant positive impact on the organizational performance [1]. Growth and competitiveness of banks are dependent on the successful application of new technologies. Availability of skilled labor is a questionable resource requirement. There is a qualitative and quantitative imbalance in the supply of skilled labor. It depends on the demographic factors, business cycles and rapid technological advancements taking place around us. Due to the vast development in the area of e-Banking it is essential that the policy makers should focus on the growing demand in ICT skills and take corrective steps to prepare the required numbers and quality beforehand. e-Banking enables to conduct banking business electronically over the Internet where the costs are minimal and it is no longer bound by time or geographical boundary.

How can the Sri Lankan banks keep abreast of these changes? How can the banks stay ahead and introduce next generation of banking products? The answers to these questions would be to have employees fluent in digital language and people who are innovative and creative. They should be capable in introducing new banking products and understanding the future banking needs of our society. This research provides information to the stakeholders of commercial banks to allocate required funds for the much-needed ICT training on employees. Further, ICT literacy level of the decision makers has a huge impact on the total customer satisfaction and thereby achieving growth in performance.

\section{B. Experienced Before the Implementation of} ICT Facilities

There were many constraints and hardships experienced by bank branches in the era of preICT usage. The total number of accounts handled manually by branches with the allocated staff members was limited. Hence the opening of new accounts was restricted in most of the high level branches. Today there is no restriction as such and systems allow the opening of any number of accounts. 
Before the implementation of Automatic Teller Machines (ATMs) customers had to visit their own branch to withdraw cash. Anytime banking was not available. Unavailability of any-where banking features was due to the unavailability of ATM banking, Internet banking, SMS and phone banking. Branches were opened only during the specified time durations. Banking hours were restricted. Branch staff could not leave the branch until they balance their day's accounting. In some instances, balancing was extended to late nights. Daily balancing, month-end balancing and year-end balancing were tedious tasks to operational staff of the branch. Branches had to offer more restricted banking hours during such periods.

If a customer wanted to withdraw money from his savings account, he had to fill a savings debit form, present it to the cashier, obtain a token and wait till the number is called. When the token number is called, he had to place the signature again on the same debit voucher confirming cash receipt from the cashier. Accordingly he had to visit the cashier at least twice to receive his own money. There were no single point transactions. Branch staff had to check signatures, mandates and ledger sheets and they need to make necessary entries manually before disbursing or after accepting cash from customers. There were long waiting queues at branches on special days when the branch staff could not handle the workload. Fund transfer between two accounts belonging to separate branches or banks was a complicated task and it took several days to effect the transaction. Reconciliation of main accounts took many days and they were usually two to three days behind. Extraction of past records was a task of searching through huge paper files and documents. But today, a customer can receive cash from the branch teller at the first appearance. Tellers are given authority to pay up to a higher level without seeking officers approval. Tellers can review all the information on-line using the teller terminals before taking decisions. Debit voucher forms are validated on- line using teller printers.

Customer advices and statements were type written. Even the balance inquiry was a complex task. Job expertise was a mandatory requirement to work at the branch. Customers were given lengthy account numbers as the branch codes and ledger numbers were incorporated in account numbers for easy identification. There was no easy way to extract instant ad-hoc MIS reports for decision-making. There were no cashless shopping, marketing or holidaying. People had to carry cash with them. Credit cards and debit cards were not available.

\section{Problem Statement}

Most bank branches at present are equipped with main core banking applications supported by a central computer system. Island-wide ATM networks are also linked to branches and run on separate software applications. Banks are also equipped with 'intranets' providing much functionality along with e-mail facilities to branches. Internet banking, SMS banking and phone banking are also being provided as value added services. Credit card usage is also popular among customers. Branches are initiating the issue of credit cards and debit cards (ATM cards). Also it is the branch that attracts customers for Internet banking access. They are also using word processing software, spreadsheet applications and Internet for day to day operations in addition to the use of core banking applications.

Banks are spending huge sums of monies in acquiring ICT competence. They need to invest huge amounts in foreign currency for hardware, software and soft skills. Also they invest money to train bank staff and maintain and retain the group of knowledge workers. Do the banks gain the expected return on expenditure? Have they achieved the maximum value for the money spent? Do they have a specific plan to collect the return? Also, does the bank prepare its entire staff to accept ICT challenges and innovations ahead?

\section{Research Objectives}

The main objective of this research is to find out the impact of ICT usage on branch performance. With respect to a leading commercial bank in Sri Lanka, this study attempts to measure the impact of ICT usage on bank branch performance. It also tries to find out the level of ICT usage at branches. Further the study attempts to explore the ICT literacy level of banking staff.

\section{E. Scope of the Study}

The research was carried out within a set of sample branches belonging to a bank involved in commercial banking business in Sri Lanka.

\section{F. Importance of the Study}

There are many factors governing the overall performance of banks. It is necessary to study all the factors and their effectiveness on the performance. In this era of e-Banking ICT definitely plays a major role in performance. Almost all the banks in Sri Lanka are geared with complex ICT systems to handle core-banking functionalities. Branches use those functionalities provided by the central core banking applications. However, the usage of ICT at the branch, other than the core banking 
application is to be studied. Also it is necessary to motivate and encourage branch managers and the staff to be equipped with ICT skills to use ICT in a broader way.

The results of this research will enable the banks to take corrective decisions on fund allocations for ICT training of their staff. They can include alterations to the recruitment and promotion criteria to consider ICT skill levels. This can result in making it a general requirement to acquire ICT skills for employment in the banking industry. This will also create awareness in the general public that it is important to acquire basic ICT skills before seeking employment. Finally, it can contribute in turn to improve the ICT literacy level of the general public.

If banks are willing to include ICT literacy skills in the performance evaluation and promotion criteria, it will be an added motivation for the existing bank staff to acquire required ICT skills. When the branch staff is ICT literate, they can propose and suggest innovative banking products which align with banking business. It will be easy for the specialized ICT staff to have fruitful discussions during policy reforms.

\section{RELATED WORK}

ICT is a main factor which influences globalization. Globalization is a 'social process'. Various companies from different countries with different cultural values and ideas tend to converge together. Business and society as a whole rely heavily on ICT. ICT is a means to communicate data and valuable information that is used in organizational processes for crucial decision making. With the development of the Internet there is an increased opportunity enabling organizations to succeed financially [2]. ICT has become an essential resource to business activities due to the development of high bandwidth telecommunications networking, integrated distribution systems, and database systems that allow businesses to operate in a global way. ICT enables communication between different companies via state-of-the-art technology, consisting of telecommunications equipments such as high-tech web cameras and ultra-fast networks, resulting in high-speed data transmission ${ }^{1}$.

Now that many firms around the world have taken to globalization through ICT, it has caused an increase in competition. As a result there is a benefit to the consumer. The prices set on the Internet are frequently lower than the prices set in retail stores [1]. In the book 'The Search' [3] Battelle explained how the search engine 'Google' and its rivals changed the rules of traditional business and transformed our global culture.

\section{A. ICT Literacy}

There are many definitions for ICT literacy, but all are on common themes. In 1984 the term "computer literacy" was described as "appropriate familiarity with technology to enable a person to live and cope in the modern world" and as "the skills and knowledge needed by a citizen to survive and thrive in a society that is dependent on technology for handling information and solving complex problems"[4]. More recently it is defined as "an understanding of computer characteristics, capabilities and applications, as well as an ability to implement this knowledge in the skilful and productive use of computer applications" [4]. ICT proficiency is the ability to use digital technology, communication tools, and/or networks appropriately to solve information problems in an information society. This includes the ability to use technology as a tool to research, organize, evaluate, and communicate information. The possession of a fundamental understanding of the ethical/legal issues surrounding the access and use of information is also included in ICT proficiency [5]. Table I shows the 7 factors identified by Berger to define ICT literacy [6].

TABLE I

An ICT Literacy Framework

\begin{tabular}{|l|l|}
\hline Define & $\begin{array}{l}\text { Use ICT tools to identify and represent an } \\
\text { information need }\end{array}$ \\
\hline Access & $\begin{array}{l}\text { Knowing about and knowing how to collect } \\
\text { and/or retrieve Information }\end{array}$ \\
\hline Manage & $\begin{array}{l}\text { Organize information into existing clas- } \\
\text { sification schemes }\end{array}$ \\
\hline Integrate & $\begin{array}{l}\text { Interpreting, summarizing, comparing and } \\
\text { contrasting information using similar or dif- } \\
\text { ferent forms of representation }\end{array}$ \\
\hline Evaluate & $\begin{array}{l}\text { Reflecting to make judgments about the } \\
\text { quality, relevance, usefulness, or efficiency } \\
\text { of information }\end{array}$ \\
\hline Create & $\begin{array}{l}\text { Generating new information and knowledge } \\
\text { by adapting, applying, designing, inventing, } \\
\text { or representing information }\end{array}$ \\
\hline Communicate & $\begin{array}{l}\text { Conveying information and knowledge to } \\
\text { various individuals and/or Groups }\end{array}$ \\
\hline
\end{tabular}

Assessment of ICT literacy means not just knowledge of technology, but the ability to apply technology to solve problems [5]. Findings of an e-skills study of IT user skills in workplace in the UK demonstrated very bad gaps for employees. The study has found that many employees lacked sufficient IT user skills to perform effectively in their day-to-day roles thus impacting negative business productivity [7]. 


\section{B. Use of ICT in Banking}

Dramatic changes are happening in financial products and services. Other than the traditional banking business of liquidity provision, banks have acquired competencies to perform variety of other financial and non-financial activities. Deregulation and innovation have opened up the financial sector. Bankers must ensure that they are ready for this technological change [8].

Advancement in technology prompts banks to drop the use of traditional branches and form new partnerships and delivery channels. The Internet seems to be the most popular delivery channel. Factors such as security of personal data, reliability and difficulties in using the Internet have been identified as the determinants of electronic banking adoption $^{2}$. Most banks in Sri Lanka do provide e-Banking facilities to retail customers, particularly overseas banks and a few local banks. Preliminary observations indicate that, while some customers use these e-Banking facilities on the Internet, it has still not grown to a significant level. In this context, one could see some factors that limit the ICT usage. One of them is the issue of people not having access to the Internet. For example, many people in developing countries do not have access to computers. Also there is a limitation as to how many people can use the services that organizations can provide through their websites [1]. The discussions are going on over the concept of a minimum computing skill level as an important outcome of education. Numerous terms are being used to describe this set of skills. The more familiar descriptions have included such terms as, computer awareness, computer literacy, information literacy, and information and communications technologies (ICT) literacy. There is a need to develop some form of benchmark that could be used to assess levels of ICT literacy [4].

The drive towards self-service and automated customer care has allowed organizations to reduce costs and handle an ever-increasing number of consumer transactions efficiently. However, the profile of end customer is ever changing. They are becoming mobile and not relying on a single communication device. Companies should grasp this and maintain a competitive edge. They should recognise the growing user-centricity of consumer communications [9].

The paradigm is shifting. The organisations that can move quickly to respond to this change can gain a bigger market share and reduce customer churn purely by enhancing the experience of customers who now expect anytime, anywhere access to services [9]. A research carried out in the UK has used the "Growth Accounting Approach" to multi factor productivity estimation to estimate the impact of ICT on productivity [1]. Identification of suitable metrics to assess ICT impact on business performance is a difficult task. Further work have to be carried out to determine whether measures such as ICT usage, user satisfaction could be used as an indicator of business performance attributed to the use of ICT in a competent and innovative way [10].

\section{Bank Branch Performance}

There are many factors governing the performance of decision-making units that are to be considered in benchmarking [10]. Some of them can be listed as cusotmer attitude towards ICT usage, scope of ICT applications used, level of ICT service quality, ICT security level, complexity of ICT, unreliability of ICT, job satisfaction of the staff, profitability, considering ICT as a strategic tool, level of customer relationship management, customer satisfaction, cost reduction, operational efficiency and operating efficiency. A study done on comparison of service quality states that the ICT usage on branch performance can be measured using the use of the Internet as a marketing intelligence tool, perceived usefulness and perceived ease of use, system quality (information quality), attitudes towards web retailing, compatibility, personality, working experience, educational level, Internet access availability, training received and frequency of use and trust [11].

In a research done by Davis [12] in 1989 using the Technology Acceptance Model (TAM) as a basis, a questionnaire was completed by employees. Structural Equation Modeling (SEM) was used to analyze the data, and this confirmed the relationships proposed by the TAM [12]. In that research, the TAM was modified and applied to bank customers in Estonia, because Estonia, a country with a developing economy, has focused on Internet banking as an important distribution channel. A total of 268 commercial bank customers responded to a Greek and Turkish translated version of the SERVQUAL (a multiple-item scale for measuring perceptions of service quality instrument). After descriptive and factor analysis, multivariate regression was used to estimate the impact of service quality dimensions on overall customer satisfaction and word of mouth. TAM is shown in Fig. 1.

\section{Benchmarking Decision Making Units}

Import In the research study carried out by David Wainwright and others [10] in 2005, the impact on branch performance was looked from two sides as the ICT impact and business impact. Further, the performance was studied from two angles as ICT performance to business performance [10]. A contingency approach to benchmark ICT using 


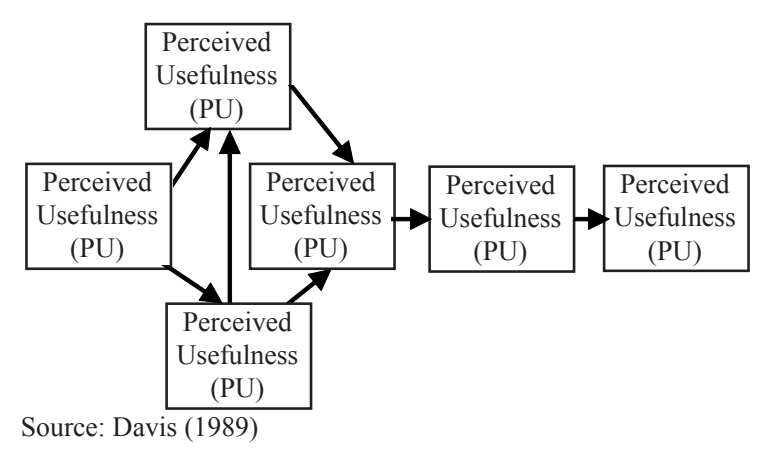

Fig. 1. Technology Acceptance Model (TAM)

skills, knowledge and competency was used for the assessment of ICT impact on business performance. Key potential benchmarking factors for firms are depicted in the framework designed by them [10] as shown in Fig. 2. Fig. 3 shows the key areas in benchmarking ICT. Key potential benchmarking factors for firms are depicted in the framework. ICT technical skills, focused practices (functional sophistication) and management of ICT practices (managerial sophistication) are linked to the impact of IT on business performance. This work yielded valuable facts for the development of more theoretical ICT benchmarking criteria. The focus on managerial and technical competences, defined in terms of appropriate skills and knowledge are determinant factors in affecting business level capability for high performance [10].

A research carried out by Ginige and Samarasinghe has studied the ICT effects on Total Quality Management (TQM) [13]. They have explained the importance of IT usage on TQM dimensions and IT practices on TQM practices for quality performance.

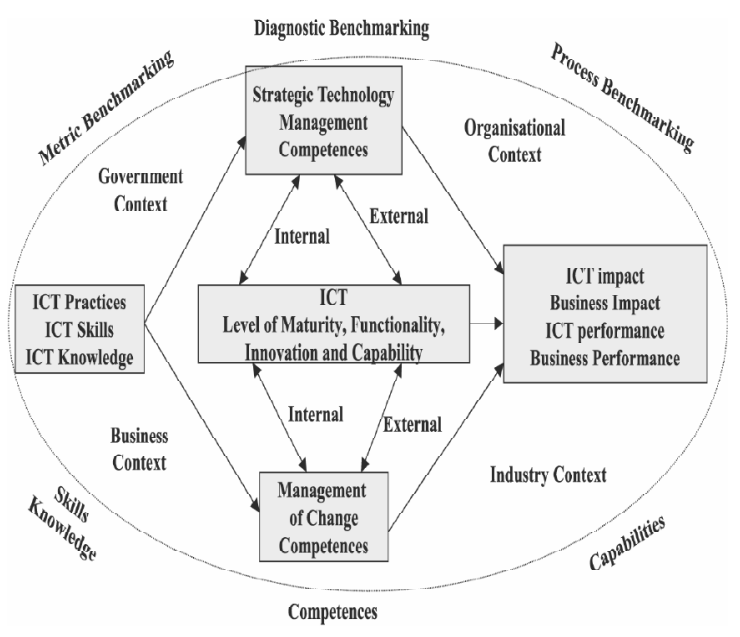

Source: Wainwright (2005)

Fig. 2. Contingency Framework for Benchmarking ICT

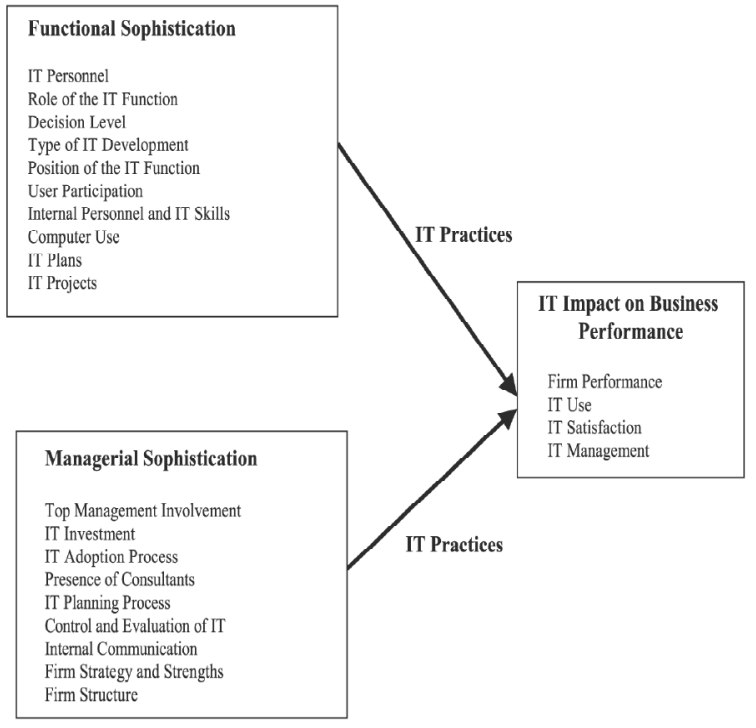

Source: Wainwright (2005)

Fig. 3. Key Areas for Benchmarking ICT

\section{Methodology}

The research was carried out on quantitative design to measure ICT usage level at branches. Interviews were carried out to collect data from key stakeholders in the banking sector who are also with ICT expertise. Functionalities that the branch staff can perform using ICT skills in order to increase the bank performance were analyzed by conducting interviews with industry experts. A sample set of branches were selected for the survey. Three types of questionnaires were prepared and distributed among the branch managers, staff and customers.

In order to measure the branch performance, the following channels were used to acquire data:

- Published data

- Customer views

- Interviews with veteran bankers

- Interviews with bank staff

- Results obtained from the questionnaire

Branch performance was measured in two ways such as quality performance and financial performance. Based on the previous literature, those two performances were measured using multiple sets of variables as explained in Table II.

Data was analyzed and presented in descriptive and narrative forms using statistical methods and SPSS (Statistical Package for Social Sciences) and finally the impact of ICT usage on bank branch performance was measured. 
A. Formulation of the Framework

TABLE II

Variables Used To Measure Branch Performance

\begin{tabular}{|c|l|}
\hline \multicolumn{2}{|l|}{ Financial Performance $(\mathbf{F P})$} \\
\hline 1 & Total deposits \\
\hline 2 & Total advances \\
\hline 3 & Branch profit \\
\hline Quality Performance (QP) \\
\hline 1 & Customer attitude on branch performance \\
\hline 2 & Customer complaints \\
\hline 3 & Job satisfaction of the branch staff \\
\hline
\end{tabular}

TABLE III

Variables Used To Measure ICT Usage At Branches

\begin{tabular}{|c|l|}
\hline \multicolumn{2}{|l|}{ ICT Application (Application) } \\
\hline 1 & Scope of ICT applications \\
\hline 2 & Availability of Internet \\
\hline 3 & ATM availability \\
\hline 4 & Level of e-mail communication \\
\hline 5 & Level of office package usage \\
\hline Attitude Towards ICT (Attitude) \\
\hline 1 & Attitude of branch managers towards ICT usage \\
\hline 2 & Attitude of branch staff towards ICT usage \\
\hline 3 & Attitude of customers towards ICT usage \\
\hline ICT Literacy Level (Literacy) \\
\hline 1 & ICT literacy level of manager \\
\hline 2 & ICT literacy level of branch staff \\
\hline 3 & ICT literacy level of customer \\
\hline
\end{tabular}

Bank branch performance was the dependent variable in the study. It is measured in two ways such as financial performance and quality performance of the branch. Independent variables are grouped under ICT usage at bank branches. Independent and dependent variables used for the analysis are detailed in Tables II and III.

\section{B. Conceptual Model for the Investigation}

According to the objectives of the research the following conceptual framework (Fig. 4) was developed.

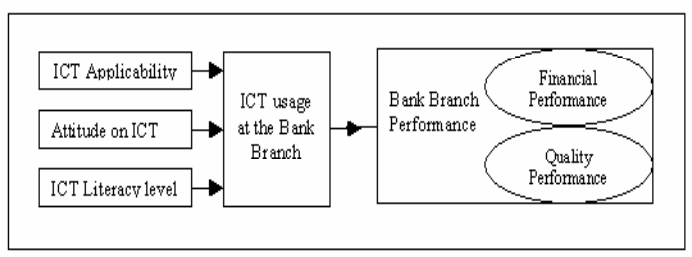

Fig. 4. Research Framework

\section{Results}

\section{A. Correlation Analysis}

Pearson's correlation analysis was used to identify the relationships of performance variables with ICT usage variables to test the hypothesis. Results obtained are shown in the Tables IV, V, VI and Table VII.

TABLE IV

Correlation Analysis Between ICT Usage And Increase In Deposits

\begin{tabular}{|c|r|r|r|r|}
\hline & $\begin{array}{c}\text { Increase } \\
\text { in } \\
\text { Deposits }\end{array}$ & $\begin{array}{c}\text { Ap- } \\
\text { plica- } \\
\text { tion }\end{array}$ & $\begin{array}{c}\text { Atti- } \\
\text { tude }\end{array}$ & $\begin{array}{c}\text { Lit- } \\
\text { eracy }\end{array}$ \\
\hline $\begin{array}{c}\text { Increase in Pearson } \\
\text { Correlation }\end{array}$ & 1 & .461 & $518(*)$ & .401 \\
\hline Deposits Sig.(2-tailed) & & .054 & .028 & .099 \\
\hline $\mathrm{N}$ & 18 & 18 & 18 & 18 \\
\hline
\end{tabular}

* Correlation is significant at the 0.05 level (2-tailed)

TABLE V

Correlation Analysis Between ICT Usage And Increase In AdVANCES

\begin{tabular}{|c|r|r|r|l|}
\hline & $\begin{array}{c}\text { Increase } \\
\text { in } \\
\text { Deposits }\end{array}$ & $\begin{array}{l}\text { Appli- } \\
\text { cation }\end{array}$ & $\begin{array}{l}\text { Atti- } \\
\text { tude }\end{array}$ & $\begin{array}{l}\text { Lit- } \\
\text { eracy }\end{array}$ \\
\hline $\begin{array}{c}\text { Increase in Pear- } \\
\text { son Correlation }\end{array}$ & 1 & .459 & $.557\left(^{*}\right)$ & $.534\left(^{*}\right)$ \\
\hline $\begin{array}{c}\text { Deposits Sig. } \\
\text { (2-tailed) }\end{array}$ & & .055 & .016 & .022 \\
\hline $\mathrm{N}$ & 18 & 18 & 18 & 18 \\
\hline
\end{tabular}

* Correlation is significant at the 0.05 level (2-tailed)

TABLE VI

Correlation Analysis Between ICT Usage And Increase In PROFIT

\begin{tabular}{|c|c|c|c|c|}
\hline & $\begin{array}{l}\text { Increase } \\
\text { in } \\
\text { Deposits }\end{array}$ & $\begin{array}{l}\text { Appli- } \\
\text { cation }\end{array}$ & Attitude & Literacy \\
\hline $\begin{array}{l}\text { Increase in } \\
\text { Pearson Cor- } \\
\text { relation }\end{array}$ & 1 & $.474(*)$ & $.661(* *)$ & $.650(* *)$ \\
\hline $\begin{array}{c}\text { Deposits Sig. } \\
\text { (2-tailed) }\end{array}$ & & .047 & .003 & .033 \\
\hline $\mathrm{N}$ & 18 & 18 & 18 & 18 \\
\hline
\end{tabular}

** Correlation is significant at the 0.01 level (2-tailed)

TABLE VI

Correlation Analysis Between ICT Usage And Increase In PROFIT

\begin{tabular}{|l|r|r|}
\hline \multicolumn{3}{|c|}{ Correlation Analysis Between ICT Usage and } \\
Quality Performance \\
\hline & QP & ICT Usage \\
\hline QP Pearson Corre & 1 & $.727(* *)$ \\
\hline Sig.(2-tailed) & 18 & .001 \\
\hline N & & 18 \\
\hline$*$ Correlation is significant at the 0.01 level (2-tailed)
\end{tabular}




\section{B. Hypothesis Testing}

The following hypotheses were tested.

\section{Hypothesis 1}

"Higher the ICT application at bank branch, higher the impact on increase in branch deposits".

Correlation analysis showed that there is no strong relationship.

$\begin{array}{ll}\text { Accepted } & \mathrm{H}_{0} \\ \text { Rejected } & \mathrm{H}_{1}\end{array}$

TABLE VIII

Summarised Results From Correlation Analysis

\begin{tabular}{|l|c|l|}
\hline Variable & $\begin{array}{l}\text { Pearson Correla- } \\
\text { tion }\end{array}$ & $\begin{array}{l}\text { Significance } \\
\text { (2- tailed) }\end{array}$ \\
\hline \multicolumn{2}{|c|}{ Increase in Deposits } \\
\hline ICT Application & .461 & .054 \\
\hline Attitude towards ICT & $.518\left(^{*}\right)$ & .028 \\
\hline ICT literacy Level & .401 & .099 \\
\hline \multicolumn{2}{|c|}{ Increase in Advances } \\
\hline ICT Application & .459 & .055 \\
\hline Attitude towards ICT & $.557\left(^{*}\right)$ & .016 \\
\hline ICT literacy Level & $.534\left(^{*}\right)$ & .022 \\
\hline \multicolumn{2}{|c|}{ Increase in Profit } \\
\hline ICT Application & $.474\left(^{*}\right)$ & .047 \\
\hline Attitude towards ICT & $.661\left(^{* *}\right)$ & .003 \\
\hline ICT literacy Level & $650\left(^{* *}\right)$ & .003 \\
\hline \multicolumn{2}{|c|}{ Quality Performance } \\
\hline ICT usage & $727\left(^{*}\right)$ & .001 \\
\hline
\end{tabular}

*Correlation is significant at the 0.05 level (2-tailed)

** Correlation is significant at the 0.01 level (2-tailed)

\section{Hypothesis 2}

"Greater the positive attitude towards ICT, higher the impact on increase in branch deposits at the bank branch".

Correlation analysis showed a positive relationship.

Rejected $\quad \mathrm{H}_{0}$

Accepted $\quad \mathrm{H}_{2}$

\section{Hypothesis 3}

"Higher the ICT literacy level of branch staff and customers, higher the impact on increase in bank branch deposits".

Correlation analysis showed that there is no strong relationship.

$\begin{array}{ll}\text { Accepted } & \mathrm{H}_{0} \\ \text { Rejected } & \mathrm{H}_{3}\end{array}$

\section{Hypothesis 4}

"Higher the ICT application at bank branch, higher the impact on increase in advances".
Correlation analysis showed that there is no strong relationship.

$\begin{array}{ll}\text { Accepted } & \mathrm{H}_{0} \\ \text { Rejected } & \mathrm{H}_{4}\end{array}$

\section{Hypothesis 5}

"Greater the positive attitude towards ICT, higher the impact on increase in advances at the bank branch". Correlation analysis showed a positive relationship. $\begin{array}{ll}\text { Rejected } & \mathrm{H}_{0} \\ \text { Accepted } & \mathrm{H}_{5}\end{array}$

\section{Hypothesis 6}

"Higher the ICT Literacy level of branch staff and customers, higher the impact on increase in bank branch advances".

Correlation analysis showed a positive relationship.

$\begin{array}{ll}\text { Rejected } & \mathrm{H}_{0} \\ \text { Accepted } & \mathrm{H}_{6}\end{array}$

\section{Hypothesis 7}

"Higher the ICT application at bank branch, higher the impact on increase in the branch profit."

Correlation analysis showed a positive relationship.

Rejected $\quad \mathrm{H}_{0}$

Accepted $\quad \mathrm{H}_{7}$

\section{Hypothesis 8}

"Greater the positive attitude towards ICT, higher the impact on increase in Profit of bank branch".

Correlation analysis showed a strong positive relationship.

$\begin{array}{ll}\text { Rejected } & \mathrm{H}_{0} \\ \text { Accepted } & \mathrm{H}_{8}\end{array}$

\section{Hypothesis 9}

"Higher the ICT Literacy level of the branch staff and the customers, higher the impact on the increase in bank branch profit".

Correlation analysis showed a strong positive relationship.

$\begin{array}{ll}\text { Rejected } & \mathrm{H}_{0} \\ \text { Accepted } & \mathrm{H}_{9}\end{array}$

\section{Hypothesis 10}

"Higher the ICT usage level, higher the impact on Quality Performance improvement at the bank branch".

Correlation analysis showed a strong positive relationship.

$\begin{array}{ll}\text { Rejected } & \mathrm{H}_{0} \\ \text { Accepted } & \mathrm{H}_{10}\end{array}$




\section{DisCUSSION}

There is a significant positive relationship between the attitude of the branch staff plus customers towards the ICT usage and the increase in branch performance. There is a weak positive relationship between the ICT application and the increase in deposits. The relationship between IT literacy level of the staff and the customers and the increase in branch deposits is also weak. It is noted that this bank could use ICT as a marketing intelligence tool to increase deposits.

The relationship between the increase in advances of the branch and the attitudes of the staff plus customers towards ICT is significant. Increase in advances with the ICT literacy level of staff and customers are also significantly related. However, the ICT application has only a weak relationship with the increase in advances of branch. With the use of ICT, it was possible to evaluate the customer credit worthiness in granting advances. However, according to the results it can be stated that this bank was utilizing the power of ICT to increase the loan and advance portfolio of the bank. They could get the advantages of data warehousing and data mining to evaluate customers and increase loan portfolio.

All three independent variables listed as ICT application, attitude towards ICT and ICT literacy level have strong relationships with the dependent variable named as increase in branch profit. The relationship with attitude towards ICT and ICT literacy level is stronger. It is seen that the relationship between ICT usage and quality performance of a branch is also significant. Branch staff is able to attend to customer needs in a better way as they could access customer information online. They could verify the signatures online. Total customer profile could be viewed with a single key stroke. ICT has made the work easy for the branch staff.

The research study showed that there is a substantial influence of ICT usage on the bank branch performance improvement. In conducting this research it was found that usage levels of ICT in the branches differed significantly. Some branches were using ICT in many of their business functions whereas in others the ICT usage was limited to core banking applications. For example, some branches have not explored the possibility of using e-mail communication with customers to further improve customer service levels and reduce delays in correspondence.

Some branches were responding to customer e-mails promptly whereas others were not putting much effort on checking e-mails on time. In some branches, managers themselves were accessing branch e-mails whereas in others a secretary was attending to e-mails. While most branches were using computers (with word processing software) to prepare required letters and statements, some branches still used mechanical type writers. In some branches even the branch managers were not using Internet banking.

Some of the causes of such differentiation are non availability of Internet and personal computers for the related staff, lack of ICT knowledge and poor investments on ICT at branch level. Some senior staff members were very comfortable with the way they practiced their work for past 10 to 15 years and not willing to accept changes. It was also stated that some personal computers were very slow in performance. Slowness in Internet browsing was also a concern. Some staff members were complaining about not having Internet access, because managers had the opinion that it is not possible to open Internet for all staff as it can have an adverse effect on normal work.

The analysis proved that the use of ICT has a huge impact on the overall branch profit. Establishment of the core banking application system with on-line inter branch network covering most of the branches in the island has increased the convenience of customers. Anytime banking and anywhere banking has reduced customer visits to his/her own branch.

Most of the customers have not seen the web site of the bank. It is possible to have a display desktop at the reception counter of the branch with bank web site as home page for customer use. It is also necessary to address the issue of bank branch staff not having access to the Internet. Some staff members have not even accessed the web site of the bank.

The ICT literacy level of the branch staff can be further improved and facilities should be available at the branch to use ICT for branch work. Core banking application to be further strengthened to reduce staff time spent on routine work. Staff should be free to use ICT for new avenues such as to enhance the deposit mobilization, the advance portfolio and recovery of non-performing loans.

From the research findings it was revealed that ATM usage is very popular among customers. However, customers are not happy with the level of ATM availability in the country. ATM locations are limited and it is not easy to find another ATM machine when the closest one is not functioning. Banks need to address this issue collectively. Banks can incorporate other functionalities like cash deposits and acceptance of clearing cheques via ATMs. It is necessary to amend and incorporate required legal policies pertaining to these functionalities in order to serve the customer.

Bank branches are the critical decision making units of the bank. ICT usage can be used to measure, 
benchmark and identify low performing branches. Data Envelopment analysis can be used to benchmark branches in order to get the maximum output from ICT usage [14].

In future, the entire bank branch networks in the island will be equally equipped with latest ICT functionalities. Hence the competition will lie on special attention given to customers by his or her own branch and ultimately it will be the human relationship that will bring back customers and not the technology. It will be mainly the human connection, love and care of serving customers that will attract and retain customers to the branch.

\section{ACKNOWLEDGMENT}

The support given by the staff attached to the MBA-IT programme of University of Moratuwa, the guidance given by Dr R. B. Ekanayake and the support from professional bankers are acknowledged.

\section{REFERENCES}

[1] C. Robinson and M.O. Mahony, The Growth of ICT and Industry Performance, National Institute Economic Review, 184(60), 2003.

[2] D. Needle, Business in Context: An introduction to business and its environment, 4th edition, Thomsons, 2006.

[3] J. Battelle, The Search, Penguin Group, USA

[4] R. Oliver and S. Towers, Benchmarking ICT Literacy in Tertiary Learning Settings, ASCILITE 2000, A.S.F. Computers, Australia, 2000.

[5] I.E. Rockman, Editorial ICT Literacy, Reference Services Review, 33(2):141-143, 2005.

[6] P. Berger, ICT Literacy Assessment, Infosearcher, (http:// Infosearcher.typepad.com/infosearcher/2005/04/ict literacy as.html, accessed on 20-01-2008).

[7] S.M. Mutula and P.V. Brake, ICT Skills Readiness for the Emerging Global Digital Economy among Small Businesses in Developing Countries, Library Hi Tech, 25(2): 231-245, 2007.

[8] R.G. Rajan, Why banks have a future: Towards a new theory of commercial banking, Journal of Applied Corporate Finance, 9(2): 114-128, 1996.

[9] A. Lucent, Improving Customer Satisfaction Through More Effective ICT Strategies, 2007 (http://www.bitpipe. com, accessed on 21-01-2008).

[10] D.G.G.M. Wainwright and D. Yarrow, Towards a Framework for Benchmarking ICT Practice, Competence and Performance in Small Firms, The International Journal for Library and Information Services, 6(1): 39-52, 2005.

[11] H. Arasli, A Comparison of Service Quality in the Banking Industry. Some Evidence from Turkish- and Greekspeaking areas in Cyprus, International Journal of Bank Marketing, 23(7): 508-526, 2005.

[12] F. D. Davis, Perceived usefulness, perceived ease of use, and user acceptance of information technologies, MIS Quarterly, 13(3): 319-40, 1989.

[13] H. R. Ginige and S. M. Samarasinghe, Impact of ICT on Total Quality Mgt, Proceedings of the 5th International Conference on Business Management, Colombo, 2008.

[14] A. C. Soteriou and Y. Stavrinides, An Internal Customer Service Quality Data Envelopment Analysis Model for Bank Branches, International Journal of Operations \& Production Management, 17(8): 780-789, 1997. 